\title{
WALKING THE PARTY LINE? THE DETERMINANTS OF FACEBOOK'S ADOPTION AND USE BY CZECH PARLIAMENTARIANS
}

\section{Alena Macková :: Václav Štětka}

IZVORNI ZNANSTVENI RAD / DOI: 10.20901/ms.7.14.11 / PRIMLJENO: 01.04.2016.

ABSTRACT The last few years have witnessed an intensified academic debate on the potential of online social networking sites (SNSs) in the Czech Republic. However, the ensuing academic discussions focused mostly on the SNS pages of political parties. Politicians in particular have recently become the focus of attention in the shift towards research exploring the use of SNSs. The aim of this paper is to provide insight into the role of Facebook in the communication of parties and candidates during the Czech parliamentary elections in 2013. We analyse the adoption of Facebook as a mobilization tool by seven parties as well as by 200 individual deputies, looking for similarities and differences in terms of the adoption, strategy and engagement of users. Although party influence seems to be a significant predictor of Facebook adoption, our data also indicate that using other digital channels increases the chances of higher engagement on Facebook at the individual level.

\section{KEY WORDS}

FACEBOOK, ONLINE SOCIAL NETWORKING SITES, PARLIAMENTARY ELECTION, THE CZECH REPUBLIC

Authors note

Alena Macková :: Charles University, Faculty of Social Sciences, Prague and Masaryk University, Faculty of Social Studies, Brno, the Czech Republic :: aja.mackova@gmail.com

Václav Štětka :: Loughborough University, Department of Social Sciences, UK and Charles University, Faculty of Social Sciences, the Czech Republic :: v.stetka@lboro.ac.uk

The authors acknowledge the support of the Czech Science Foundation (GAČR), Standard Grant number 14-05575S - "The role of social media in the transformation of political communication and citizen participation in the Czech Republic". 


\section{INTRODUCTION}

Social media have made an impressive entry into the realm of politics over the course of the last several years, significantly enriching the ways politicians and political parties can reach out to and engage with voters, and substantially transforming the established patterns of communication between political actors, journalists and citizens in general (see Howard, 2006). Online social networking sites have created new opportunities for politicians and parties to mobilize supporters, bypass mainstream news media in their effort to spread political messages, and even set the news agenda as journalists are increasingly relying on social media as sources for news. These - and other - obvious benefits have contributed to the growing adoption of social networking sites as instruments of political communication across the world, particularly in the context of election campaigns.

Consequently, the academic research on the adoption and use of social networking sites for political communication has recently blossomed. However, in Central and Eastern Europe the academic reflection of this phenomenon has been somewhat delayed when compared with Western Europe or the US, at least when considering studies reaching the international community, as those have only started mushrooming within the last couple of years, mostly as single country case studies (e.g. Baranowski, 2015; Merkovity, 2014). In Czechia, the interest in social networking sites as instruments of campaign communication was sparked by the presidential campaign of Karel Schwarzenberg in 2013, which demonstrated the potential of social media (and Facebook in particular) to mobilize young voters (Štětka et al., 2014). However, even though the subsequent 2013 Czech Parliamentary elections and the 2014 European Parliamentary elections brought opportunities for empirical investigation (Štětka and Vochocová, 2014), these studies focused mainly on the analysis of the adoption of SNSs at the party level, while devoting no attention to the use of social media by individual candidates. In this respect, the scholarship exploring the role of new media in campaign communication in the Czech Republic (and in CEE region in general) still displays notable gaps, particularly when compared to the state of research in Western Europe and the US (Carlson and Strandberg, 2008; Gibson, 2010; Gulati and Williams 2013; Larsson and Kalsnes, 2014).

This study aims to fill this research gap and empirically examine the adoption and use of social media by political candidates during the campaign for the 2013 Czech parliamentary elections, while focusing on individual, contextual and technological factors influencing the level of SNS adoption and impact in terms of users' engagement. In doing so, we are attempting to explore the extent to which candidates' Facebook strategies are congruent with their own parties' use of the same social media network for the campaign, or whether there are any individual divergences from the patterns of use and engagement observed at the party level. Given that most studies conducted in this area so far have focused either on the party level or the individual level of use, we are hoping that this innovative research design, in combining the two approaches, can surpass the geographical scope of this particular case study, and enrich the existing scholarship on the role of social media in campaign communication. 


\section{THEORETICAL CONTEXT}

Within the literature on the use of new media by political actors, there is a predominant orientation towards exploring patterns of the use of digital technologies as tools for electoral communication (e.g. Larsson and Kalsnes, 2014; Williams and Gulati, 2013). A significant number of studies investigating the role of SNSs in electoral communication has been designed with the aim of answering the question, whether the patterns of political communication established in the offline environment is replicated in the online domain (the so-called normalization thesis, see Margolis and Resnick, 2000), or whether the new digital platforms have some transformative potential and offer opportunities for the otherwise marginalized political actors to level the playing field ("equalization thesis"). While the latter perspective assumes that the online media give voice and visibility, particularly to those groups and actors who have been struggling to get heard in the traditional media space, according to the normalization thesis new media merely reinforce power relationships that existed prior to the digital age, with the stronger, resource-rich parties and individual actors benefiting the most from the arrival of these new technologies (Gibson et al., 2000). This view is also complementary to the diffusion of innovations theory as presented by Everett Rogers (1986, 1995), according to which early adopters of new media are more often male, young, with a higher socioeconomic status - and they likely utilize other media channels as well.

In line with Rogers's theory, some studies have confirmed that the age of the politician determines how she approaches new media. As Anders Larsson and Bente Kalsnes (2014) and Kim Strandberg $(2009,2013)$ observe, perhaps unsurprisingly, young politicians in Norway, Sweden and Finland adopt and use Facebook more often than their older counterparts. Some older studies identified differences between genders in the use of new media channels by politicians and candidates (for review, see Larsson and Kalsnes, 2014), while according to the newer research, these differences have been diminishing (Larsson and Kalsnes, 2014; Strandberg, 2009; Vergeer and Hermans, 2012).

Another factor researchers have paid attention to in their search for determinants of SNS adoption has been the incumbency of the candidate and their position on the candidate list. While some studies (e.g. Carlson and Strandberg, 2008; Williams and Gulati, 2013; Strandberg, 2013) tend to rather confirm the normalization hypothesis (incumbents being more active in their usage of new media), Larsson and Kalsnes (2014) found the opposite pattern in the candidates' use of Twitter. One of the most commonly tested factors has been the size of the party, with evidence pointing in the direction of the normalization hypothesis (Carlson and Strandberg, 2008; Lilleker and Koc-Michalska, 2013; Strandberg, 2009, 2013; Williams and Gulati, 2007), the newer study by Larsson and Kalsnes (2014) suggests that in 2013 candidates from smaller parties adopted and used SNSs more frequently than their competitors, even though the effect of this link was fairly limited.

While studies looking at parties and candidates' processes of adopting new communication technologies initially suggested the predominance of the equalization effects, contemporary research tends to gravitate towards the confirmation of the 
normalization thesis, although the literature is still far from fully conclusive. Given the quickly approaching saturation point in the adoption of new media by the political parties and individual politicians, the literature's attention has shifted from studying the mere adoption of new technologies, towards the more detailed examination of their use, exploring the size of the networks, the ability to mobilize and engage potential voters, and the overall effect on citizens' political behavior. Research shows that it is usually just a few candidates who are able to generate a large number of followers online (Nielsen and Vaccari, 2013: 2351; Vaccari and Nielsen, 2013). In terms of parties, it seems that those that are either bigger (Larsson, 2015) or display populist or progressive features (Graham et al., 2016; Larsson, 2016; Vergeer et al., 2013) tend to be more successful in reaching fans on social media, as they are generally, also more active in communication on SNS (Grant et al., 2010; Vergeer et al., 2013).

The interaction between politicians/parties and social media users is another popular research domain, even though studies tend to primarily examine the direction from political actors to citizens (Graham et al., 2016; Ross et al., 2015; Sorensen, 2016). It is often pointed out that politicians and party/campaign managers are very keen on talking about the importance of interaction, rather than actually engaging in them (Enli and Skogerbø, 2013; Sorensen, 2016). There are hints from existing research that it is particularly the candidates from the main political parties, as well as incumbents, who manage to stimulate higher engagement on the side of users, rather than candidates from alternative or non-parliamentary parties and challengers for the office (Williams and Gulati, 2013; Xenos et al., 2015).

In summary, research into the factors that lie behind the intensity and form of political parties and candidates' adoption of social media for electoral communication has been rather inconclusive. This can be partly explained by the fact that the data has often come from different political contexts and systems, as well as from different types of elections. Notably, most of the studies have been from a very limited number of countries and regions, while others have been largely neglected so, including the CEE region, which further underscores the importance of broadening the geographical research scope in order to obtain more diverse base for comparison and for testing the above quoted theories. Also, to our knowledge, there have been no systematic attempts to simultaneously examine the use of new media at both the party level and the level of individual candidates. Together, by investigating the relationship between parties' and candidates' social media adoption and the engagement of users, our paper hopes to fill the existing lacuna in the literature. We believe there is a theoretical incentive for such a research design, namely the fact that the normalization theory - despite often serving as the main theoretical framework for the study of SNS adoption and use - has mainly been tested with regards to adoption, while engagement has often been left out of the picture. 


\section{METHODOLOGY}

In order to add to this growing, but still fragmented research field, we have designed an empirical analysis of the adoption and use of Facebook by political candidates and parties during the 2013 Czech parliamentary elections. The study was driven by two main research questions:

$>$ How did the intensity of Facebook use and user engagement, differ between parties and individual candidates?

$>$ What were the main determinants of the adoption and use of Facebook by the candidates?

We decided to operate with two dependent variables for both individual candidates and parties. The first one was the adoption of Facebook, defined as the possession of an active Facebook account (min. 1 public status at least 11 days before the elections). The second dependent variable was engagement, defined as the ability of the party or candidate to stimulate action on the side of the other Facebook users, measured by the number of "likes," comments and shares related to individual statuses. We assume that the greater intensity of such activities indicates higher engagement, and therefore a potential impact on those messages on fans, friends and other users of this social networking site.

Given the exploratory character of the first part of the research, we have refrained from formulating a hypothesis related to the first research question, also because of the lack of previous research, which would indicate a particular type of relationship to test. However, we do expect to find similarities, rather than differences, in the patterns of usage of Facebook by the candidates and their parties; in other words, we believe it is likely that parties which are themselves active on Facebook will also have candidates that are more active in terms of Facebook adoption and also use (because of party pressure, peer pressure, the access to know-how and expertise available at the party level). Drawing on the previous research, we also expect some variability in the adoption and engagement among candidates' Facebook activity - variability that could be explained by other than party factors. With regards to candidates' Facebook activity we have included three types of independent variables into our research design: individual, contextual and technological. The first group of individual variables are sociodemographic ones - age and gender. Based on the previous research and inspired by Rogers's diffusion of innovation theory (1995) we formulated the following hypotheses:

H1: Younger candidates will display a higher level of adoption ( $\mathrm{H} 1 \mathrm{a})$ and engagement (H1b) (see Larsson and Kalsnes, 2014; Strandberg, 2013).

$\mathrm{H} 2$ : There will be no difference between male and female candidates in adoption (H2a) and engagement (H2b) (see Strandberg, 2009; Vergeer and Hermans, 2012).

The other sub-group of individual variables consists of political ones: incumbency and leadership position. We suppose, following the normalization thesis, that incumbents 
and leaders (the first person on the list of candidates in the region, that is, the regional leader) will be more active, either because of the internal distribution of resources within the party, because of greater experience, and also supposedly higher public prominence.

H3: Incumbents will display a higher level of adoption ( $\mathrm{H} 3 \mathrm{a})$ and engagement $(\mathrm{H} 3 \mathrm{~b})$ than challengers (see Gulati and Williams, 2013).

$\mathrm{H} 4$ : Leaders will display a higher level of adoption ( $\mathrm{H} 4 \mathrm{a})$ and engagement $(\mathrm{H} 4 \mathrm{~b})$ than lower-ranked candidates (see Strandberg, 2009).

We also considered the influence of broader party context which might have an impact on the levels of Facebook adoption and engagement by individual candidates. In this respect, we examine party position and differentiate between parliamentary and extra-parliamentary parties. We suppose, in accordance with the normalization thesis that due to the (financial and organizational) resources available to candidates from parliamentary parties, those candidates will be comparatively more active on Facebook.

H5: Candidates from parliamentary parties will display a higher level of adoption ( $\mathrm{H} 5 \mathrm{a})$ and engagement $(\mathrm{H} 5 \mathrm{~b})$ than those not represented in parliament.

The third and last type of independent variable concerns technological factors. We suppose (in line with the diffusion of innovation theory) that using other new media platforms will positively influence candidate's activity on Facebook.

H6: Candidates that actively use multiple new media platforms will display a higher level of adoption ( $\mathrm{H6a}$ ) and engagement $(\mathrm{H} 6 \mathrm{~b})$ than those relying only on Facebook (see Williams and Gulati, 2013).

\section{DATA}

Since the study aims to analyse new media activity by individual candidates as well as parties, it relies on a combination of two separate data sets, both collected within the period of 11 days before the snap 2013 Parliamentary Elections (October 25-26). The sample consisted of all elected parties (7) and candidates ( $\mathrm{N}=200) .{ }^{1}$ Data from Facebook were manually archived, partly using the plug-in ScrapBook for Mozilla Firefox (in case of parties). Altogether, 1954 statuses produced by 105 deputies with active Facebook accounts (both profiles and pages with public statuses) and 504 statuses by parties, both with metadata about engagement with statuses, were collected. Additional information

\footnotetext{
1 The decision to include only the elected candidates was based on the necessity to reduce the sample to a manageable size and, at the same time, to implement clear and efficient selection criteria. Given the nature of the electoral system in the Czech Republic where parliamentary elections take place in 14 regional constituencies with separate candidates' lists, the construction of a representative sample of the individual candidates represents a major research challenge. In addition, the objectives of our research required the collection of candidate's socio-demographic data which would have been much more difficult to obtain for many lower-ranked candidates who did not enter into the Parliament. Still, we are fully aware that the scope of our sample poses certain limitations for the interpretation of our study's outcomes.
} 
about the candidates (socio-demographic profile, position on the list, etc.) were collected using publicly available sources, like their websites or the website of their political party, or from the website of the Chamber of Deputies of the Czech Parliament.

\section{RESULTS}

\section{Adoption and voters' engagement at the party level}

The Czech party political system has been regarded as relatively consolidated since the late 1990s, with two dominant parties regularly alternating power (the Civic Democratic Party and the Social Democratic Party) and two other parties with stable electoral support and representation in Parliament (the Communist Party and the Christian Democratic Party). However, this system started becoming fragmented in 2010, due to the formation and electoral success of new parties, including populist ones. The subsequent instability culminated in the 2013 snap elections, which were marked by a near-victory of the new populist movement YES 2011 led by the businessman and billionaire Andrej Babiš. The YES 2011 movement managed to gain $18.6 \%$ of the vote, less than $2 \%$ behind the winner, the Social Democratic Party (20.4\%). Apart from YES 2011, another new populist party which entered the Parliament after the 2013 elections was Dawn of Direct Democracy led by Tomio Okamura (6.9\% of votes).

The majority of Czech political parties first adopted social media during the campaign for the 2010 Parliamentary Elections. Since 2010, social media have been used by parties and candidates ever more intensely; two years later more than half of the candidates in the Senate elections already had their Facebook account (Macková et al., 2013). As evidenced by a survey among party communication managers, for most parties Facebook became an important communication tool (Lilleker et al., 2015). In 2013, all the seven parties which exceeded the $5 \%$ threshold and entered the Czech Parliament had an official Facebook page at the time of the elections, even though some of them established it relatively recently (e.g. Dawn of Direct Democracy or the Communist Party). As it is apparent from the Graph 1, while the conservative TOP 09 had far the biggest base of Facebook fans before the election campaign, it was the new populist YES 2011 party that made the most out of the online campaign, having gained 15 thousand new fans during the period of one and half weeks before the elections. Likewise, the Dawn of Direct Democracy managed to attract new supporters, adding nearly four thousand fans to its Facebook page during the campaign. The TOP 09 party gained even slightly more fans in the same period (4223). The established parties (Social Democrats, Civic Democratic Party, and Communist Party) did not manage to mobilize almost any new supporters, a result consistent with a relatively low effort invested into their Facebook campaigns, as evidenced by the number of statuses posted per day (Table 1). 


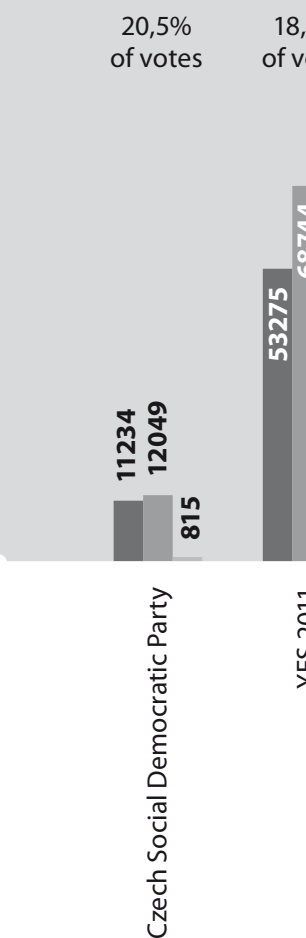

Page likes at the start of the campaign

Page likes on the election day

Sum $\mathrm{Nr}$ of likes gained during campaign

$8,6 \%$

$14,9 \%$

\section{$11,9 \%$}

$7,7 \%$

$6,9 \%$

$6,8 \%$

of votes

of votes

of votes

of votes

of votes

of votes
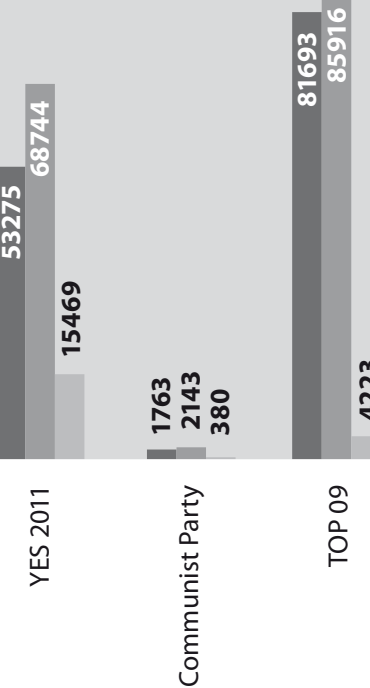

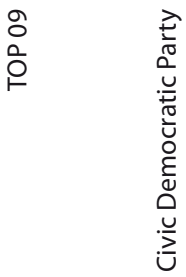
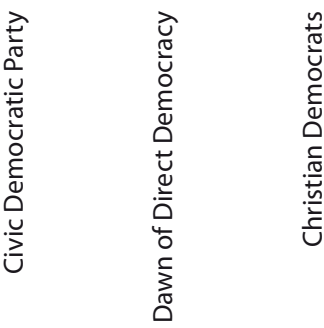

$\Delta$ Graph 1.

The development of the number of fans of political parties on Facebook and parties' electoral results (\% of votes) Period October 14 - 24, 2013.

Overall, the new populist parties were also comparatively more successful in stimulating users' engagement, as measured by the standard metrics (likes, shares, comments). YES 2011 led the table in both the amount of likes and comments per post (Table 1), while the Dawn of Direct Democracy had the second highest amount of shares per post, behind only the Social Democrats whose frequency of party posts was however three times as low. Apart from these two populist parties, it was only TOP 09 - the party established only in 2009 and aiming at the younger, urban electorate - which managed to achieve similarly high levels of engagement, while the traditional parties lagged behind in the attention received from Facebook users (see Štětka and Vochocová, 2014). 
Table 1. Activity and engagement on the Czech political parties' Facebook pages

\begin{tabular}{|c|c|c|c|c|c|c|c|c|}
\hline & \multirow[t]{2}{*}{$\mathrm{N}$} & \multirow{2}{*}{$\begin{array}{l}\text { Posts } \\
\text { daily }\end{array}$} & \multicolumn{2}{|l|}{ Likes } & \multicolumn{2}{|c|}{ Comments } & \multicolumn{2}{|c|}{ Shares } \\
\hline & & & Mean & Std. Dev. & Mean & Std. Dev. & Mean & Std. Dev. \\
\hline $\begin{array}{l}\text { Czech Social } \\
\text { Democratic Party }\end{array}$ & 30 & 2.7 & 148.6 & 55.2 & 86.9 & 25.7 & 119.8 & 54.5 \\
\hline YES 2011 & 89 & 8.1 & 462.7 & 446.6 & 121.6 & 97.3 & 70.4 & 91.4 \\
\hline Communist Party & 7 & 0.6 & 105.7 & 49.2 & 53.1 & 28.4 & 20.9 & 19.5 \\
\hline TOP 09 & 110 & 10 & 272.5 & 369.3 & 83.4 & 94.8 & 43.5 & 62.1 \\
\hline $\begin{array}{l}\text { Civic Democratic } \\
\text { Party }\end{array}$ & 63 & 5.7 & 128.5 & 102.9 & 45.3 & 55.6 & 26 & 37.4 \\
\hline $\begin{array}{l}\text { Dawn of Direct } \\
\text { Democrats }\end{array}$ & 97 & 8.8 & 251.6 & 211.3 & 47.1 & 35.9 & 86.6 & 96.2 \\
\hline Christian Democrats & 108 & 9.8 & 77.4 & 81.2 & 24.4 & 26.1 & 26 & 45.5 \\
\hline
\end{tabular}

Period October, $14-24,2013 ; n=510$.

\section{Levels and determinants of Facebook adoption by candidates}

The analysis of Facebook activity and users' engagement on the level of individual candidates reveals a rather different picture. Arguably the most visible divergence between the central party strategy and elected MPs' own approach to this online platform was observed in the case of YES 2011, whose Facebook party profile came out as the liveliest of all the parties elected to the Parliament; however, only a third of the elected MPs used Facebook in the election campaign (see Graph 2) - the second lowest number of all the parties, leaving behind only the MPs from the Communist Party. On the other hand, almost all the MPs from the Dawn of Direct Democracy had an active account, with a very centralized design.

It is apparent that the party's approach towards the management of its own social media platforms does not fully determine the candidates' adoption and level of activity on these networks; therefore, they must be also influenced by other factors. Almost one quarter of the Communist Party MPs found their way to Facebook sooner than the party itself, as the party established its official Facebook profile only just before the elections. On the other hand, the YES 2011 candidates did not turn to Facebook in great numbers, despite the fact that the party had a very active and diverse fan base on this social network. 


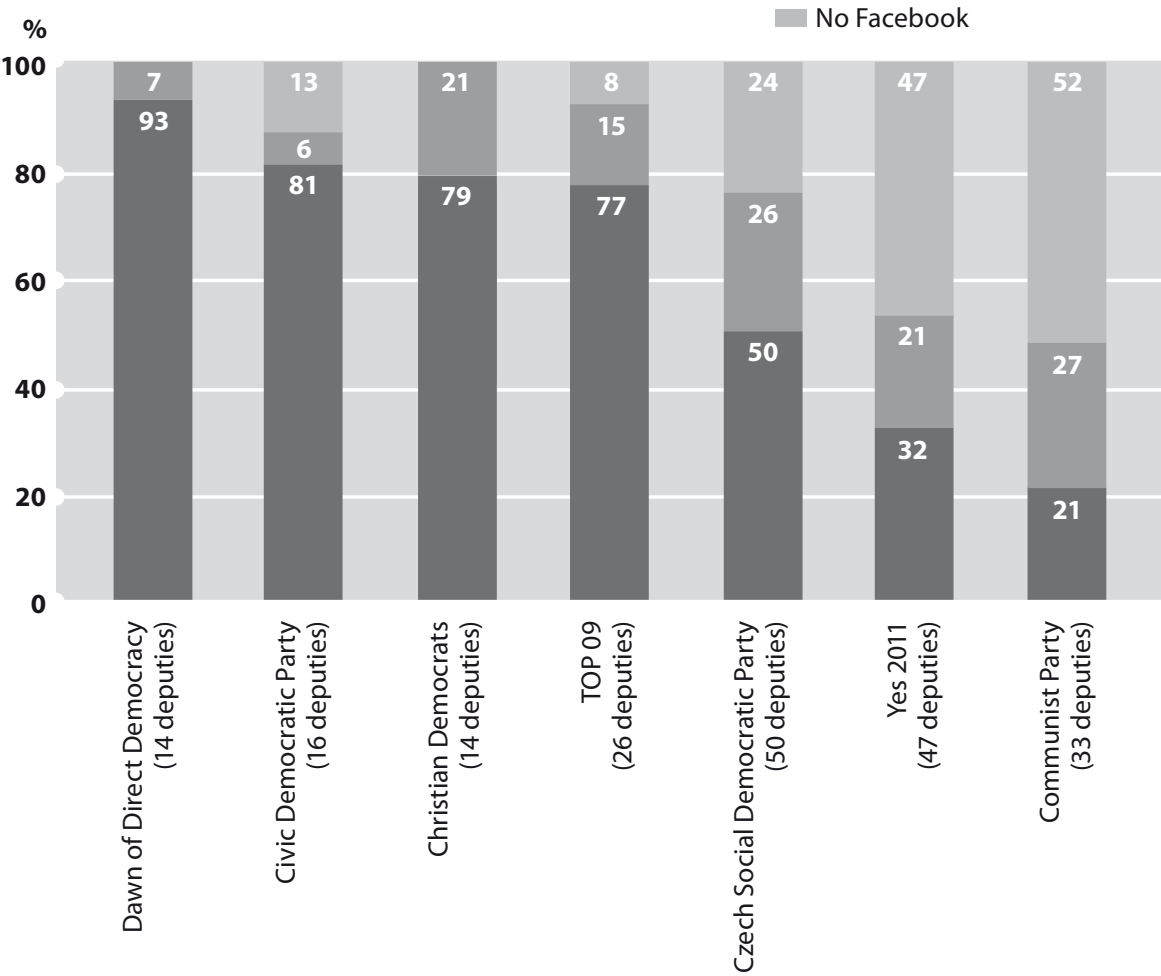

$\Delta$ Graph 2. Adoption of Facebook prior to the 2013 election campaign by newly elected MPs. Period October $14-26,2013 ; n=200$.

Therefore, in order to explore other factors which could influence candidates' willingness to use Facebook, we use a regression model involving three clusters of variables - individual, contextual and technological. The model (see Table 2 ) reveals that there is no relationship between gender and adoption ( $\mathrm{H} 2 \mathrm{a}$ confirmed), but surprisingly also no relationship between either age (H1a not confirmed) or a candidate's incumbency ( $\mathrm{H} 3 \mathrm{a}$ not confirmed) and the adoption of Facebook. The position of the leader of the candidate's list, however, comes out as a significant predictor of adoption - there is a 2.3 times greater chance that leaders of the candidates' lists will use Facebook than the others; however, it has to be noted that when accounting for technological factors, this link disappears (H4a partly confirmed).

In terms of our contextual variable, the parliamentary or extra-parliamentary status of a candidate's party seems not to have played any role in his/her decision to adopt 
Facebook ( $\mathrm{H} 5 \mathrm{a}$ not confirmed). The adoption of other communication platforms representing the third, "technological" cluster of the variables in our model - turns out to be a positive predictor for the adoption of Facebook (H6a confirmed), with Twitter showing the strongest link (and blogs, the weakest one). It is apparent that those candidates who already have experience with one such medium have a tendency to add more to it.

Table 2. Factors influencing the adoption of Facebook by MPs (binary logistic regression)2

\begin{tabular}{|c|c|c|c|c|c|c|c|c|c|}
\hline & B & $\operatorname{Exp}(B)$ & S.E. & B & $\operatorname{Exp}(B)$ & S.E. & B & $\operatorname{Exp}(B)$ & S.E. \\
\hline Gender & 0.35 & 1.43 & 0.38 & 0.36 & 1.44 & 0.38 & 0.53 & 1.69 & 0.42 \\
\hline Age & -0.03 & 0.97 & 0.01 & -0.03 & 0.97 & 0.01 & -0.03 & 0.97 & 0.02 \\
\hline Incumbents & 0.18 & 1.20 & 0.30 & 0.28 & 1.32 & 0.38 & 0.15 & 1.16 & 0.46 \\
\hline Leader & ${ }^{* *} 0.83$ & 2.29 & 0.30 & ${ }^{* *} 0.81$ & 2.24 & 0.31 & 0.04 & 1.05 & 0.38 \\
\hline $\begin{array}{l}\text { Parliamentary } \\
\text { parties }\end{array}$ & & & & -0.16 & 0.85 & 0.38 & -0.46 & 0.63 & 0.46 \\
\hline Website & & & & & & & 2.95 & 0.37 & $* * 1.08$ \\
\hline Twitter & & & & & & & 18.07 & 0.80 & $* * * 2.89$ \\
\hline YouTube & & & & & & & 1,08 & 0,82 & 0.07 \\
\hline Blog & & & & & & & 3.59 & 0.59 & ${ }^{*} 1.28$ \\
\hline-2 Log likelihood & & & 264.03 & & & 263.86 & & & 212.34 \\
\hline $\begin{array}{l}\text { Nagelkerke } \\
\text { R Square }\end{array}$ & & & 0.082 & & & 0.083 & & & 0.367 \\
\hline
\end{tabular}

The important role of other channels is confirmed not only in the case of the mere adoption of Facebook, but also, and more significantly, when it comes to the candidates' Facebook activities and the intensity of user engagement with the MPs' profile.

However, before elaborating on the actual data, it has to be mentioned that three of the candidates had to be excluded from the analysis due the fact that they were significant outliers in terms of engagement. ${ }^{3}$ Only one third of the newly elected MPs with an active Facebook account had more than one thousand fans/friends (see Graph 4), and - as in the case of the study by Rasmus Kleis Nielsen and Cristian Vaccari (2013) - the majority of politicians were rather ignored by citizens on Facebook.

\footnotetext{
Multicollinearity test was performed, with the VIF statistics being lower than 2 for each of our independent variables; therefore we can say that there is no multicollinearity in our model.

${ }^{3}$ The most followed politician - Karel Schwarzenberg - had over 200 thousand friends. It would have been therefore misleading to compare the average activities or engagement on his profile with the other candidates, just as in case of Tomio Okamura (leader of Dawn of Direct Democracy, almost 80000 fans) or Miroslav Kalousek (the leader of the TOP 09 candidate list, more than 20000 fans).
} 


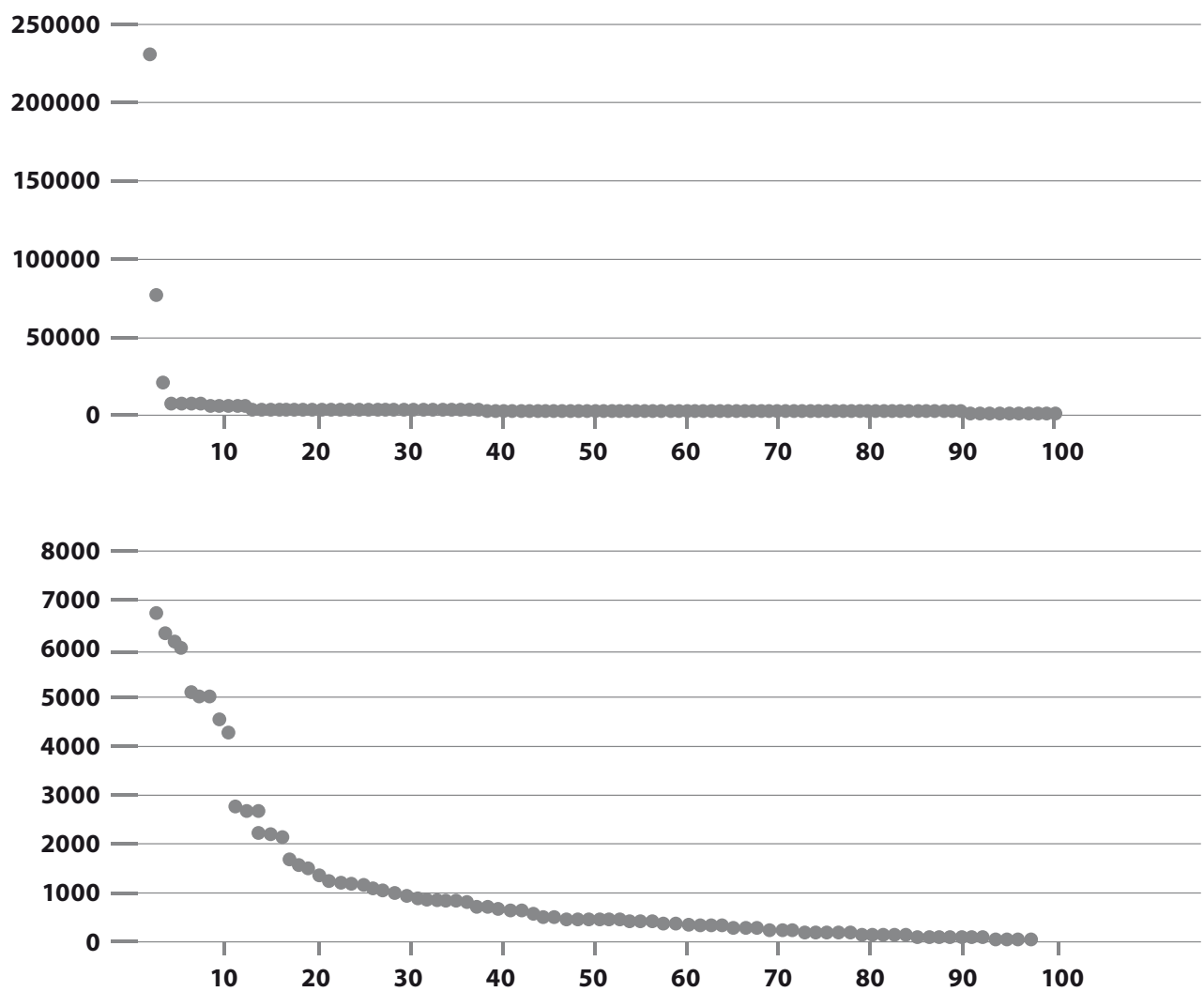

$\Delta$ Graphs 3 and 4.

The distribution of the number of friends/fans on the candidates' profiles - with and without the outliers (the values on the $\mathrm{X}$ axis represent percentages) Data from 26 October 2013 (second election day).

\section{Candidates' activity and users' engagement}

In terms of the activity and engagement with posts among candidates from different parties, there is also a certain discrepancy in the case of YES 2011 at both the party and individual level. Although the public profile of YES 2011 was very active during the campaign period in terms of the number of statuses and user engagement as well (see Table 1), the candidates from this party were among the less active ones (see Table 3), and engagement with their posts was rather average. Relatively higher activity and also higher engagement was displayed by the candidates from the Civic Democratic Party, who could be seen as political "veterans" in comparison with newcomers from YES 2011 or 
the Dawn of Direct Democracy. It also must be noted that the campaign communication of the two populist parties was very much centred on the party leaders, which might have contributed to the lower motivation of the other candidates to express themselves and seek engagement via the social networking sites. Lower engagement was also recorded by the Christian Democrats and the Communist Party candidates, in correlation with the figures displayed at the party level.

Table 3. Candidates' activity and engagement on Facebook, by parties

\begin{tabular}{|c|c|c|c|c|c|c|c|c|}
\hline & \multirow{2}{*}{$\begin{array}{l}\text { Posts } \\
\text { per } \\
\text { deputy }\end{array}$} & \multirow{2}{*}{$\begin{array}{l}\text { Posts } \\
\text { daily }\end{array}$} & \multicolumn{2}{|l|}{ Likes } & \multicolumn{2}{|c|}{ Comments } & \multicolumn{2}{|l|}{ Shares } \\
\hline & & & Mean & Std. Dev. & Mean & Std. Dev. & Mean & Std. Dev. \\
\hline $\begin{array}{l}\text { Czech Social } \\
\text { Democratic Party }\end{array}$ & 20.7 & 1.9 & 14.6 & 20.9 & 4.4 & 6 & 3.1 & 27.3 \\
\hline YES 2011 & 14.7 & 1.3 & 12.3 & 28.9 & 5.8 & 12 & 1.6 & 2.1 \\
\hline Communist Party & 11.4 & 1 & 12.3 & 11 & 4 & 3 & 2.2 & 1.6 \\
\hline TOP 09 & 21.1 & 1.9 & 11.4 & 17.2 & 2.1 & 3.6 & 1.2 & 1.6 \\
\hline $\begin{array}{l}\text { Civic Democratic } \\
\text { Party }\end{array}$ & 23.1 & 2.1 & 24.6 & 21.8 & 8.4 & 10.3 & 3.9 & 5.2 \\
\hline $\begin{array}{l}\text { Dawn of Direct } \\
\text { Democrats }\end{array}$ & 14.2 & 1.3 & 12 & 10.9 & 2.5 & 2.6 & 4 & 4.9 \\
\hline Christian Democrats & 19.9 & 1.8 & 7.4 & 4 & 1.2 & 1.5 & 1.8 & 2 \\
\hline
\end{tabular}

$\mathrm{N}=102$

Apart from finding notable variances between the Facebook activities of parties and their individual candidates, a difference of means test confirmed ${ }^{4}$ (see Table 4) that there are significant differences in the engagement of other Facebook users on the profiles or pages of candidate list leaders and those who are positioned in less favourable places on the candidates' lists. The statuses of the leaders were more likely to be "liked," commented and shared more often ( $\mathrm{H} 4 \mathrm{~b}$ confirmed). No other individual or contextual variables had any significant effect on the dependent variable $(\mathrm{H} 1 \mathrm{~b}, \mathrm{H} 3 \mathrm{~b}, \mathrm{H} 5 \mathrm{~b}$ not confirmed; $\mathrm{H} 2 \mathrm{~b}$ confirmed). However, this is not the case when testing for the influence of technological variables (H6b confirmed, with the exception of blogs) i.e., the simultaneous adoption of other social media by the candidates. It turns out that those who have a website, use Twitter or YouTube get more "likes" to their Facebook statuses, which are also more often commented on (and more shared as well, in the case of Twitter and YouTube). This could be explained by the greater online visibility of those MPs who are active on multiple platforms, whose content can also be used for sharing and cross-promotion across platforms.

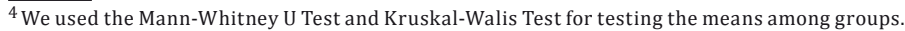


IZVORNI ZNANSTVENI RAD / DOI: 10.20901/ms.7.14.11 / PRIMLJENO: 01.04.2016.

Table 4. Candidates' activity and engagement on Facebook

\begin{tabular}{|c|c|c|c|c|c|c|c|c|c|}
\hline & \multicolumn{2}{|c|}{ Nr. of posts } & \multirow{2}{*}{$\begin{array}{l}\text { Likes } \\
\text { Mean }\end{array}$} & \multirow[b]{2}{*}{ Std.dev } & \multicolumn{2}{|c|}{ Comments } & \multirow{2}{*}{$\begin{array}{l}\text { Shares } \\
\text { Mean }\end{array}$} & \multirow[b]{2}{*}{ Std.dev } & \multirow[b]{2}{*}{$\mathrm{N}$} \\
\hline & Mean & Std.dev & & & Mean & Std.dev & & & \\
\hline \multicolumn{10}{|l|}{ Gender } \\
\hline Male & 19.1 & 18 & 14.6 & 20.5 & 4.6 & 7.8 & 2.7 & 5 & 80 \\
\hline Female & 17.2 & 13.8 & 10.6 & 13.6 & 2.1 & 2.6 & 1.8 & 2.9 & 22 \\
\hline \multicolumn{10}{|l|}{ Age } \\
\hline $21-34$ & 20.2 & 13.8 & 11.9 & 9 & 3 & 2.4 & 1.5 & 1.3 & 9 \\
\hline $35-49$ & 21.1 & 17.7 & 12 & 11.6 & 3.7 & 4.3 & 3.3 & 6.1 & 45 \\
\hline $50+$ & 16.1 & 17.1 & 15.8 & 25.4 & 4.6 & 9.4 & 2 & 3.2 & 48 \\
\hline \multicolumn{10}{|l|}{ Position } \\
\hline Incumbent & 19.7 & 16.6 & 16.3 & 20.8 & 4.3 & 5.4 & 2 & 2.8 & 43 \\
\hline Challenger & 17.9 & 17.9 & 11.9 & 11.9 & 3.9 & 3.9 & 2.9 & 2.9 & 59 \\
\hline Leader & 19.3 & 15.7 & $* * * 18.6$ & 24.2 & $* 4.8$ & 7.6 & $* * * 3.1$ & 3.7 & 48 \\
\hline Not leader & 18.1 & 18.4 & $* * * 9.4$ & 11.9 & *3.4 & 6.5 & $* * * 2.1$ & 5.4 & 54 \\
\hline \multicolumn{10}{|l|}{ Party position } \\
\hline Parliamentary & 20.3 & 16.4 & 15.6 & 19.4 & 4.5 & 6.6 & 2.6 & 5.3 & 39 \\
\hline Non-parliamentary & 16.1 & 18 & 10.7 & 18.8 & 3.4 & 7.7 & 2.4 & 3.3 & 39 \\
\hline \multicolumn{10}{|c|}{ Website } \\
\hline Yes & $* 20.4$ & 16.2 & ${ }^{*} 15.5$ & 19 & $* 4.8$ & 7.6 & 3 & 5.6 & 63 \\
\hline No & ${ }^{*} 15.8$ & 18.4 & $* 11$ & 19.4 & *2.8 & 6 & 1.8 & 2.3 & 39 \\
\hline \multicolumn{10}{|l|}{ Twitter } \\
\hline Yes & $* * 21.5$ & 12.7 & $* * 18.8$ & 24.8 & $* * 6.8$ & 10.6 & $* * 3.3$ & 3.8 & 31 \\
\hline No & $* * 17.4$ & 18.6 & $* * 11.5$ & 15.9 & $* * 2.9$ & 4.3 & $* * 2.2$ & 5 & 71 \\
\hline \multicolumn{10}{|l|}{ YouTube } \\
\hline Yes & 24.8 & 22.5 & $* * * 27.7$ & 20.6 & $* * 9.4$ & 11.9 & $* * 9$ & 11.7 & 9 \\
\hline No & 18.1 & 16.5 & $* * * 12.4$ & 18.6 & $* * 3.5$ & 6.3 & $* * 1.9$ & 2.7 & 93 \\
\hline \multicolumn{10}{|l|}{ Blog } \\
\hline Yes & $* * 26.6$ & 18.7 & 16.9 & 18.5 & 4.7 & 6 & 2.5 & 3.2 & 25 \\
\hline No & ${ }^{* *} 16.1$ & 15.8 & 12.7 & 19.4 & 3.9 & 7.4 & 2.6 & 5 & 77 \\
\hline
\end{tabular}

Mann-Whitney U Test and Kruskal-Wallis (age); ${ }^{*} p<0.05 ;{ }^{* *} p<0.01 ;{ }^{* * *} p<0.001 ; n=102$.

\section{DISCUSSION AND CONCLUSIONS}

Even though research on factors influencing adoption and intensity of use of new media has recently been multiplying, in the CEE region this topic has been largely neglected so far. In an attempt to help close this research gap, we tried to offer a concise picture of how the most widespread social networking site, Facebook was used by parties and candidates during the campaign for the 2013 Parliamentary Elections in the Czech Republic. The first 
goal of our research was to look for similarities or discrepancies between Facebook use at the party and individual level, to explore the potential effect of the parties on candidates (in terms of adoption and activity, as well as in terms of the engagement of their potential voters' networks). The Czech Facebook users clearly paid considerable attention to the two brand new populist parties, YES 2011 and the Dawn of Direct Democracy, but at the individual level the YES 2011 candidates displayed the lowest adoption rate and also a very low ability to attract the attention of Facebook users. We believe this can be to a significant extent explained by the leader-oriented campaign strategy of both populist parties, organizing most of the online communication around the leaders who gain the bulk of SNS users' attention. When looking at the more traditional parties, the picture is quite different - there seems to be a more visible connection between party strategy and the activity of the candidates. These observed patterns imply the existence of different strategies among the parties as such.

The second aim of our research was to examine other factors that could influence the adoption, activity and engagement with Facebook posts written by the candidates. We assumed that candidates with certain characteristics - corresponding with the assumptions of the normalization thesis and the diffusion of innovation theory, as well as with the findings of previous research - would be more likely to use Facebook, more active in contributing to their account, and also that their posts would gain more attention. The data from our study confirm in some aspects the findings from earlier research (e.g. Carlson and Strandberg, 2008; Strandberg, 2009), showing that sociodemographic factors are generally a weak predictor of the use of SNSs by politicians. In our case we found no significant effect of age and gender on the adoption or engagement $(\mathrm{H} 1 \mathrm{a} / \mathrm{b}$ not confirmed, $\mathrm{H} 2 \mathrm{a}$ /b confirmed). Neither an incumbent position at the individual level nor the parliamentary status of the party played any role in terms of adoption and engagement, either ( $\mathrm{H} 3 \mathrm{a} / \mathrm{b}$ and $\mathrm{H} 5 \mathrm{a} / \mathrm{b}$ not confirmed). Out of the individual and contextual variables, only the status of the leader turned out to be in some aspects a significant factor in the candidates' use of Facebook. While the mere adoption of Facebook by leaders seems to be moderated by other technological factors (H4a partly confirmed), leaders do gain more attention and their posts on Facebook display higher engagement in terms of likes, comments and shares as well (H4a confirmed).

An interesting finding is the apparently high importance of using other digital channels for success on Facebook ( $\mathrm{H6a}$ /b confirmed), which gives an advantage to those more technologically savvy candidates who are able to utilize and alternate between multiple platforms. These results are in concord with Philip N. Howard's thesis about the rise of the "hypermedia campaign" (Howard, 2006) as a response to the multi-channel environment politicians have to adapt to in the $21^{\text {st }}$ century, by trying to diversify their communication portfolio, rather than focusing on just one or two channels. Future research should, therefore, focus specifically on the type of politicians who are extensive users of new media, in order to better understand their strategies of adoption and use of these technologies. It can be assumed that the individual motivations of politicians' use of new media will also play an important role here. The key to understanding politicians' attitudes and their approach towards new media could therefore be found by focusing 
IZVORNI ZNANSTVENI RAD / DOI: 10.20901/ms.7.14.11 / PRIMLJENO: 01.04.2016.

more on the routine, off-campaign, everyday forms of use, as Anders Larsson and Jakob Svensson (2014) have suggested, possibly employing more in-depth, qualitative research strategies which would counterbalance the natural limitations of the kind of quantitative macro-level perspective used in this study.

\section{References}

>Baranowski, Paweł (2015) Online Political Campaigning during the 2014 Regional Elections in Poland. Media and Communication 3 (4): 35-44. DOI: 10.17645/mac.v3i4.368.

$>$ Carlson, Tom and Strandberg, Kim (2008) Riding the Web 2.0 Wave - Candidates on YouTube in the 2007 Finnish National Elections. Journal of Information Technology \& Politics 5 (2): 159-174. DOI: 10.1080/19331680802291475.

$>$ Enli, Gunn Sara and Skogerbø, Eli (2013) Personalized Campaigns in Party-centred Politics: Twitter and Facebook as Arenas for Political Communication. Information, Communication \& Society 16 (5): 757-774. DOI: 10.1080/1369118X.2013.782330.

$>$ Geber, Sarah and Scherer, Helmut (2015) My Voter, My Party, and Me: American and German Parliamentarians on Facebook. Journal of Information Technology \& Politics 12 (4): 360-377. DOI: 10.1080/19331681.2015.1101037.

>Gibson, Rachel. K., Newell, James L. and Ward, Stephen J. (2000). New Parties, New Media: Italian Party Politics and the Internet. South European Society and Politics 5 (1): 123-136. DOI: 10.1080/13608740508539595.

$>$ Graham Todd, Jackson, Dan and Broesma, Marcel (2016) New Platform, Old Habits? Candidates' use of Twitter during the 2010 British and Dutch General Election Campaigns. New Media \& Society 18 (5): 765-783. DOI: 10.1177/1461444814546728.

$>$ Grant, Will J., Moon, Brenda and Grant Janie Busby (2010) Digital Dialogue? Australian Politicians' Use of the Social Network Tool Twitter. Australian Journal of Political Science 45 (4): 579-604. DOI: 10.1080/10361146.2010.517176.

>Gulati, Girish J. 'Jeff' and Williams, Christine B. (2013) Social Media and Campaign 2012:

Developments and Trends for Facebook Adoption. Social Science Computer Review 31 (5): 577-588. DOI 10.1177/0894439313489258.

>Howard, Philip N. (2006) New Media Campaigns and the Managed Citizen. New York: Cambridge University Press. DOI: 10.1017/CBO9780511615986 (edition 2005).

>Larsson, Anders O. and Kalsnes, Bente (2014) 'Of Course we are on Facebook': Use and non-use of Social Media among Swedish and Norwegian Politicians. European Journal of Communication 29 (6): 653-667.

>Larrson, Anders O. and Svensson, Jakob (2014) Politicians Online. Identifying Current Research Opportunities. First Monday 19: 4-7 April. http://firstmonday.org/ojs/index.php/fm/article/ view/4897/3874 (23.04.2016). DOI: 10.5210/fm.v19i4.4897.

>Lilleker, Darren. G. and Jackson, Nigel A. (2011) Elections 2.0: Comparing e-campaigns in France, Germany, Great Britain and the United State, pp. 96-116 in Schweitzer, Eva Johanna and Albrecht, Steffen (ed.) Das Internet im Wahlkampf [The Internet during Campaigns]. Wiesbaden, Germany: VS Verlag für Sozialwissenschaften. DOI: 10.1007/978-3-531-92853-1

>Lilleker, Darren G., Jens Tenscher and Štětka, Václav (2015) Towards Hypermedia

Campaigning? Perceptions of New Media's Importance for Campaigning by Party Strategists in Comparative Perspective. Information, Communication \& Society 18 (7): 747-65. DOI: 10.1080/1369118X.2014.993679.

>Lilleker, Darren G. and Koc-Michalska, Karolina (2013) Online Political Communication Strategies: MEPs E-representation and Self-representation. Journal of Information Technology and Politics 10 (2): 190-207. DOI: 10.1080/19331681.2012.758071. 
>Lilleker, Darren G., Koc-Michalska, Karolina, Schweitzer, Eva Johanna, Jacunski, Michal, Jackson, Nigel and Vedel, Thierry (2011) Informing, Engaging, Mobilizing or Interacting: Searching for a European Model of Web Campaigning. European Journal of Communication 26 (3): 195-213. DOI: $10.1177 / 0267323111416182$.

>Macková, Alena, Fialová, Marta and Štětka Václav (2013) Nová média jako nástroj politické kampaně v České republice: případová studie krajských a senátních voleb 2012 [New Media as a Tool of Political Campaigns in the Czech Republic: a Case Study of the Regional Council and Senate Elections 2012]. Politologický časopis 13 (4): 507-525.

$>$ Margolis, Michael and Resnick, David K. (2000) Politics as Usual: The Cyberspace Revolution. Walnut Creek, CA: AltaMira.

$>$ Merkovity, Norbert (2014) Hungarian Mp's Response Propensity to Emails, pp. 305-217 in Solo, Ashu M. G. (ed.) Political Campaigning in the Information Age (Advances in Human and Social Aspects of Technology). IGI Global. DOI: 10.4018/978-1-4666-6062-5.

$>$ Nielsen, Rasmus Kleis and Vaccari, Cristian (2013) Do People "Like" Politicians on Facebook? Not Really. Large-Scale Direct Candidate-to-Voter Online Communication as an Outlier Phenomenon. International Journal of Communication 7: 2333-2356.

$>$ Rogers, Everett M. (1995) Diffusion of Innovations. New York: Free Press.

$>$ Ross Karen, Fountaine, Susan and Comrie, Margie (2015) Facing up to Facebook: Politicians, Publics and the Social Media(ted) Turn in New Zealand. Media, Culture \& Society 37 (2): 251-269. DOI: 10.1177/0163443714557983.

>Schweitzer, Eva Johanna (2008) Innovation or Normalization in E-campaigning? A Longitudinal Content and Structural Analysis of German Party Websites in the 2002 and 2005 National Elections. European Journal of Communication 23 (4): 449-470. DOI: 10.1177/0267323108096994.

$>$ Sorensen, Mads P. (2016) Political Conversation on Facebook - the Participation of Politicians and Citizens. Media, Culture \& Society 38 (5): 664-685. DOI: 10.1177/0163443715620924.

$>$ Strandberg, Kim (2013) A Social Media Revolution or just Case of History Repeating Itself? The Use of Social Media in the 2011 Finish Parliamentary Elections. New Media \& Society 15 (8): 1329-1347.

$>$ Strandberg, Kim (2009) Online Campaigning: An Opening for the Outsiders? An Analysis of Finnish Parliamentary Candidates' Websites in the 2003 Election Campaign. New media \& Society 11 (5): 835854.DOI: 10.1177/1461444809105355.

>Strandberg, Kim (2006) Parties, Candidates and Citizens Online: Studies of Politics on the Internet. Åbo: Åbo Akademis Förlag.

>Štětka, Václav, Macková, Alena and Fialová, Marta (2014) A Winding Road From "Likes" To Votes: The Role Of Social Media In The 2013 Czech Presidential Elections, pp. 225-244 in Pătrut, Bogdan and Pătrut, Monica (eds) Social Media in Politics: Case Studies on the Political Power of Social Media. Cham, Heidelberg, New York, Dordrecht, London: Springer.

>Štětka, Václav and Vochocová, Lenka (2014) A Dialogue of the Deaf, or Communities of Debate? The Use of Facebook in the 2013 Czech Parliamentary Elections Campaign. Teorija in praksa 51 (6): 1361-1380.

$>$ Vaccari, Cristian and Nielsen, Rasmus Kleis (2013) What Drives Politicians' Online Popularity? An Analysis of the 2010 U.S. Midterm Elections. Journal of Information Technology \& Politics 10 (2): 208222. DOI: 10.1080/19331681.2012.758072.

>Vergeer, Maurice, Hermans, Liesbeth and Cunha, Carlos (2012) Web Campaigning in the 2009 European Parliament Elections: A Cross-national Comparative Analysis. New media \& Society 15 (1): 128-148. DOI: 10.1177/1461444812457337 (edition 2013).

>Vergeer, Maurice, Hermans, Lisbeth and Sams, Steven (2013) Online Social Networks and Microblogging in Political Campaigning: The Exploration of a New Campaign Toll and a New Campaign Style. Party Politics 19 (3): 477-501, DOI: 10.1177/1354068811407580.

$>$ Williams, Christine B. and Gulati, Girish J. 'Jeff' (2013) Social Networks in Political Campaigns: Facebook and the Congressional Elections of 2006 and 2008. New media \& Society 15 (1): 52-71. DOI: $10.1177 / 1461444812457332$. 
IZVORNI ZNANSTVENI RAD / DOI: 10.20901/ms.7.14.11 / PRIMLJENO: 01.04.2016.

>Williams, Christine B. and Gulati, Girish J. 'Jeff (2007) Social Networks in Political Campaigns:

Facebook and the 2006 Midterm Elections, paper for presentation at the American Political Science Association conference, Chicago: 30 August - 2 September.

>Xenos, Michael A., Macafee, Timothy and Pole, Antoinette (2015) Understanding Variations in User Response to Social Media Campaigns: A Study of Facebook Posts in the 2010 US Elections. New Media \& Society. http://nms.sagepub.com/content/early/2015/11/24/1461444815616617.abstract (26.11.2015). DOI: 10.1177/1461444815616617. 


\section{NA STRANAČKOJ LINIJI? KAKO ČEŠKI PARLAMENTARCI PRIIHVAĆAJU I KORISTE FACEBOOK}

\section{Alena Macková :: Václav Štětka}

SAŽETAK Posljednjih godina svjedoci smo intenzivnih akademskih rasprava o potencijalu društvenih medija u Češkoj Republici. U fokusu tih rasprava uglavnom su stranice političkih stranaka na društvenim medijima, a u posljednje se vrijeme fokus akademskih rasprava o upotrebi društvenih medija pomaknuo na političare. Cilj je ovog rada pružiti uvid u ulogu Facebooka u komunikaciji političkih stranaka $i$ kandidata za vrijeme čeških parlamentarnih izbora 2013. Analiziramo kako je sedam političkih stranaka i dvjesto političara prihvatilo Facebook kao mobilizacijski alat te tražimo sličnosti i razlike u smislu prihvaćanja, strategije i uključivanja korisnika. lako se utjecaj političke stranke čini važnom varijablom, naše istraživanje upućuje na to da je za uspjeh na Facebooku na individualnoj razini vrlo važno korištenje drugih digitalnih kanala.

KLJUČNE RIJEČI

FACEBOOK, DRUŠTVENI MEDIJI, PARLAMENTARNI IZBORI, ČEŠKA REPUBLIKA

Bilješka o autorima

Alena Macková :: Karlovo sveučilište, Fakultet društvenih znanosti, Prag i Masarykovo sveučilište, Fakultet društvenih studija, Brno, Republika Češka :: aja.mackova@gmail.com

Václav Štětka :: Sveučilište Loughborough, Odjel za društvene znanosti, Ujedinjeno Kraljevstvo i Karlovo sveučilište, Fakultet društvenih znanosti, Republika Češka :: v.stetka@lboro.ac.uk 